\title{
KUŠINGO SINDROMAS, IŠSIVYSTĘS DE்L PIKTNAUDŽIAVIMO PREDNIZOLONU: KLINIKINIS ATVEJIS
}

\author{
Kamilè Budryte் $\dot{1}^{1}$ Marius Karnickas ${ }^{2}$ \\ ${ }^{1}$ Vilniaus universiteto Medicinos fakultetas, ${ }^{2}$ Respublikine Vilniaus psichiatrijos ligoninè
}

Raktažodžiai: jatrogeninis Kušingo sindromas, prednizolonas, somatoforminis sutrikimas, funkcinis sutrikimas, kūno distresinis sutrikimas.

\begin{abstract}
Santrauka
Somatiniai simptomai, kurių priežasties neįmanoma paaiškinti jokia organine patologija atliekant diagnostinius tyrimus, yra vienas pagrindinių somatoforminių sutrikimų požymių. Nors somatinių simptomų paplitimas pirmineje sveikatos priežiūros srityje siekia iki $49 \%$, somatoforminiai sutrikimai retai diagnozuojami klinikineje praktikoje ir diagnostiniais kriterijais persidengia su funkciniais sutrikimais. Šiame straipsnyje aptariamas klinikinis atvejis, kuriame atsiskleidžia sudètinga ir užsitęsusi somatoforminių sutrikimų eiga, sukėlusi sunkias pasekmes pacientei. Besikartojančios įvairių specialistų konsultacijos ir tyrimai, gydytojų nesusitarimas ir kelių skirtingų diagnozių nustatymas lemia pacientès nepasitikèjimą paskirtu gydymu ir nesuteikiama tinkama pagalba. Tai sukèlè ne tik suprastejusią pacientès gyvenimo kokybę, bet ir sunkų piktnaudžiavimą gliukokortikoidais, Kušingo sindromo išsivystymą ir antrinių lètinių ligų atsiradimą. Taip pat pristatoma nauja pasiūlyta diagnostine kategorija, kuri galètų sujungti somatoforminius sutrikimus ir funkcinius somatinius sindromus. Tikimasi, jog tai užtikrins efektyvesnị somatoforminių sutrikimų eigos valdymą ir gydymą.
\end{abstract}

\section{Ivadas}

Somatinių simptomų, kurie nepaaiškinami jokia somatine patologija, paplitimas pirminèje sveikatos priežiūros srityje siekia iki 49\% (1). Tradiciškai juos ịprasta vadinti mediciniškai nepaaiškinamais simptomais, o jų spektras itin platus: nuo bendro nuovargio ar ịvairios lokalizacijos ir pobūdžio skausmų iki specifinių organų sistemų funkcijos sutrikimo, kaip antai dažnesnio širdies plakimo, galvos svaigimo, viduriavimo ar galūnių silpnumo (2). Simptomai vargina pacientus ilgą laiką, retai apsiriboja viena organų sistema, linkę keisti vietą. Besitęsiantys negalavimai lemia dažną lankymąsi pas įvarius gydytojus, tačiau pacientą išsamiai tiriant ir atliekant diagnostinius tyrimus šių simptomų priežastis nepaaiškèja. Pacientai koncentruoja savo mintis ị kūną ir nemalonius jutimus, vis stipriau kelia nerimą nerandama priežastis, apsilankymų skaičius pas gydytojus auga ir vis daugiau tyrimų reikalaujama atlikti, nepaisant pakartotinių neigiamų rezultatų (3). Simptomų atsiradimas aiškinamas biopsichosocialiniu požiūriu, todèl terminas „,mediciniškai nepaaiškinami simptomai“ šiandien nebetinkamas vartoti (4). Tiksliausiai šis jokia somatine patologija nepaaiškinamas simptomų pasireiškimas apibūdinamas somatoforminiais sutrikimais (SFS), tačiau tai retai naudojama klinikinè diagnozè (5). Vyraujant vieno organo sistemos sutrikimui kitų sričių gydytojai linkę diagnozuoti funkcinius sutrikimus, dažniausiai iš jų diagnozuojamas dirgliosios žarnos sindromas, fibromialgija ir lètinio nuovargio sindromas (6). Vieno konkretaus susitarimo šiems simptomams apibūdinti nebuvimas klinikineje praktikoje sukelia daugybę sunkumų. Neretai šių sutrikimų diagnostika trunka metų metus, per vẻlai pacientams užtikrinamas efektyvus gydymas. Ši problema lemia blogèjančią pacientų gyvenimo kokybę, nedarbingumą, socialini atsiskyrimą, tuo pačiu eikvojami sveikatos sistemos kaštai ir patiriama didelè našta visuomenei (7). Pateikiant ši klinikinį atveji siekiama išanalizuoti sudètingą SFS eigą ir sukeliamas pasekmes pacientui.

\section{Klinikinis atvejis}

21 metų paciente, kuriai nustatytas jatrogeninis Kušingo sindromas dèl piktnaudžiavimo prednizolonu, perkeliama iš terapinès ligoninès ị psichiatrijos ligoninę dèl pasikartojančiu judejimo sutrikimų, kurių metu išlieka sąmonè, tačiau pacientè negali pajudèti ir kalbèti. Pacientè skundžiasi nuolatiniais viso kūno įvairaus pobūdžio skausmais, sutrikusia sąnarių funkcija ir eisena. Taip pat periodiškais virškinimo sutrikimais, padidejusiu prakaitavimu, drebuliu, bendru silpnumu. 
Gyvenimo ir ligos anamnezè. Pacientė augo ir vystėsi normaliai. Vaikysteje užkietėdavo viduriai, skaudėdavo pilvą, kartojosi pykinimai, rūgavimai, įtarta somatoforminė autonominė disfunkcija. Skirti medikamentai, kurių vartojimą nutraukè. Paauglystėje pacientę pradejjo varginti epizodiniai kelių, plaštakų sąnarių skausmai. Skausmai sąnariuose stiprèjo, dèl to keitèsi ir suletėjo eisena. Grịžus iš mokyklos nelikdavo jègų ir energijos, dèl to daugiausia laiko praleisdavo namuose, vengè susitikimų su draugais. Sunkiai prisiversdavo eiti į mokyklą, nors siekè gerų rezultatų. Prastejjo atmintis, pažymiai, tapo sunku susikoncentruoti, teisingai sudèlioti mintis, rasti tinkamą žodị. İstojus ị universitetą būklè vis pablogejjo: didejjo nuovargis, intensyvejjantis skausmas, prasideję̨s nugaroje, keliuose ir plaštakose, plito ir apėmè rankas, pečius, galvą. Po kelių mėnesių studijas nutraukè ir nuo tada gyvena su tèvais, nedirba, nesimoko. Dèl jègų neturejjimo ir skausmo kojose namuose daugiausia laiko praleisdavo lovoje arba prie kompiuterio, vis rečiau išeidavo. Tapo sunku vaikščioti, eidama nebesulenkẻ kojų, neužlipo laiptais, ėmè itin atsargiai vaikščioti, kartais net kraipydama kojas. Sulaukusi pilnametystès vis labiau susirūpino savo sveikata, todèl kelis metus nuolat važinèjo pas įvairius gydytojus ir ieškojo somatinès patologijos.Pirmą kartą dèl skausmų konsultuota reumatologo. Atliktuose tyrimuose antinukleariniai antikūnai (ANA), antineutrofiliniai citoplazminiai antikūnai (ANCA), dvispiralès DNR antikūnai (anti ds-DNR), reumatoidinis faktorius (RF) neigiami, komplemento baltymai $\mathrm{C} 3 / \mathrm{C} 4$, kreatinkinazè $(\mathrm{CK})$ normos ribose, proteinograma - be kliniškai reikšmingų pakitimu, šlapimo tyrime rodikliai normos ribose. Dèl komplikuoto lètinio sinusito 19 metų skirtas dviejų savaičių gydymo kursas prednizolonu - $20 \mathrm{mg} / \mathrm{d}$. Paciente pastebejjo, jog ne tik sumažèjo nosies išskyrų, bet ir skausmai, galèjo lengviau vaikščioti. Nutraukus vaisto vartojimą, būklè pablogèdavo, todèl paciente pradejo prednizoloną vartoti be gydytojų pritarimo. Po kelių ménesių pacientę atvykus pakartotinei reumatologo konsultacijai ištiko pirmasis judejjimo sutrikimo priepuolis. Tuo metu negalèjo paeiti, kalbèti, nevaldè galūnių, sunkiau kvėpavo, tačiau sąmonès neprarado. Itarta panikos ataka, skirtas diazepamas, hospitalizuota ị reumatologijos skyrių. Stacionaraus gydymo metu paciente, besiskundžianti įvairaus pobūdžio somatiniais simptomais, konsultuota neurologų, endokrinologų, reumatologų. Pacientès imunologiniai rodikliai buvo neigiami, kraujo, šlapimo tyrimai - normos ribose, nosies gleivinès biopsijoje vaskulito požymių nèra. Duomenų už sisteminę jungiamojo audinio ligą ar sisteminį vaskulitą nerasta. Atlikta kelių sonoskopija - kelių artrito, sinovito požymių nerasta. Kitų kliniškai reikšmingų pakitimų, kuriais galima būtų paaiškinti simptomų pasireiškimą, nenustatyta. Gydytojai liepè prednizolono dozę mažinti ir nutraukti, tačiau tai padarius skausmai grị̌davo, todèl ji dozę vèl padidindavo iki $20 \mathrm{mg} / \mathrm{d}$. Po hospitalizacijos pacientè toliau kelis metus pakartotinai konsultavosi su įvairių sričių gydytojais. Atliktas galvos smegenų magnetinio rezonanso tomografijos tyrimas, neurologinès patologijos nerasta, itarta somatoforminè autonominè disfunkcija, tačiau psichiatro paskirto medikamento pacientè nevartojo dèl mieguistumo. Dar kelis kartus pacientė konsultuota reumatologų, kurie patarè mažinti prednizolono dozę visiškai nutraukiant, nes indikacijų gydymui nebuvo, taip pat diagnozuota fibromialgija, paskirta gastroenterologo konsultacija dèl dirgliosios žarnos sindromo ir psichiatro konsultacija dèl ryškaus nuovargio. Būdama 21 metų amžiaus pacientè dar kartą buvo ištikta judèjimo sutrikimo priepuolio. Jo metu merkèsi akys, buvo sunku mąstyti, kalbèti. Išliko sąmoninga, vykdè kitų žmonių paliepimus, nors pati nieko negalejo padaryti. Tuo metu buvo padidèjęs arterinis kraujo spaudimas (AKS). Atvykus ị terapinę ligoninę skirta lašelinè infuzija, antihipertenziniai vaistai, amitriptilinas. Dèl ilgalaikio prednizolono vartojimo didelèmis dozèmis nustatytas Kušingo sindromas, antinksčių funkcijos supresija. Tyrimuose - adrenokortikotropinis hormonas $(\mathrm{AKTH})<$ $5 \mathrm{ng} / \mathrm{l}$, kortizolis ryte $7,18 \mathrm{nmol} / \mathrm{l}$. Indikacijų gliukokortikoidų vartojimui nenustatyta, sudarytas prednizolono nutraukimo planas. Nustatyta antrinè arterinè hipertenzija, skirtas perindoprilis $10 \mathrm{mg} \mathrm{1k}$./d. Hospitalizacijos metu kartojosi panašūs judejjimo sutrikimo priepuoliai, kai gulinti embriono pozoje pacientè nekalbèjo, negalèjo pajudèti, tačiau sąmonès neprarado. Priepuolių metu somatinès patologijos nerasta, todèl nuspręsta pacientę perkelti ị psichiatrijos stacionarą tolimesniam ištyrimui ir diagnozès patikslinimui dèl galimų disociacinių ir somatoforminių sutrikimų.

Objektyvi apžiūra atvykus. Pacientė vidutinès būklès sunkumo, sąmoninga, kontaktiška. Kūno temperatūra $36,7^{\circ} \mathrm{C}$. Kūno sudejjimas asteniškas, kūno masès indeksas $17 \mathrm{~kg} /$ $\mathrm{m}^{2}$. Oda plona, blyški, ryškus dermografizmas, nugaroje po mentimis linijoje ties 6-7 šonkauliais horizontalios siauros, trumpos raudonos strijos. Pavienis akneforminis bėrimas veide, liemens odoje. Liežuvis sausas, su apnašu. Galūnès plonos. Veidas mėnulio formos, kušingoidinè riebalų sankaupa sprando srityje ir abipus kaklo. Širdies veikla ritmiška, AKS 170/90 mmHg, širdies susitraukimų dažnis 90 k./min. Plaučiuose alsavimas normalus vezikulinis, be karkalų. Pilvas minkštas, neskausmingas. Kojos pastoziškos, edemų nèra.

Psichikos būsena. I gydytojo kabinetą ateina lètai, vilkdama kojas. Pokalbio metu visapusiškai teisingai orientuota. Kalba noriai, daug. Emocijos neišraiškingos, monotoniškos, veide - nuolatinè neadekvati šypsena. Skundžiasi įvairios lokalizacijos kūno skausmais, bendru silpnumu, jègų neturèjimu. Paprašyta gniaužyti rankas ị kumščius, tai daro lètai, 
nepilnai, sako, kad rankos jos "neklauso", jaučia nuolatinę įtampą kūne. Skausmas maudžiančio pobūdžio, jaučiamas negiliai po oda, ivvairiose lokalizacijose: keliuose, juosmens srityje (geriausia poza siekiant šio skausmo išvengti - embriono), kakle (sieja su rentgenogramoje nustatyta osteochondroze), pečiuose, pilve (sieja su obstipacijomis). Mano, kad jos veidas "lyg pakritęs", be emocijų, jaučia lyg jis "svirtų". Skundžiasi, kad jau seniai intensyviai prakaituoja, vargina kūno drebulys, galūnių tirpimas, šalimas. Mano, kad svoris per mažas ir norètų jo priaugti. Labiau nerimauja dèl sveikatos, o ne dèl išvaizdos pokyčių. Spuoguotumo, veido formos pakitimų, odos sausumo nesieja su prednizolono vartojimu.

Atlikti tyrimai. Automatizuotas kraujo tyrimas atvykus: leukocitų skaičius - $10.23 \times 10^{9} / 1$; eritrocitų skaičius - 5.1 x $10^{12} / 1$; hemoglobino kiekis - $134 \mathrm{~g} / 1$; trombocitu skaičius - 407 x10 $/ 1$; neutrofilų skaičius - $6.52 \times 10^{9} / 1$. Leukograma: be blastų. Bendrasis šlapimo tyrimas: be pokyčių. Biocheminis kraujo tyrimas: kalis - $4.6 \mathrm{mmol} / \mathrm{l}$, natris - $143 \mathrm{mmol} / \mathrm{l}$, gliukozès kiekis - $4.64 \mathrm{mmol} /$. Kraujo krešumo rodikliai: normos ribose. Atlikus pilvo organų echoskopiją, nustatytos neaiškių ribų cistos inkstų srityje, hipoechogeniškas darinys antinksčių srityje. AKTH $<5 n g / 1$.

Pacientė stacionare gydyta amitriptilinu iki $100 \mathrm{mg} / \mathrm{d}$., vèliau pridedant pregabalino $150 \mathrm{mg} / \mathrm{d}$. Antrinè arterinè hipertenzija gydyta propranololiu $40 \mathrm{mg} / \mathrm{d}$. Taikytas atsipalaidavimo mokymas, užimtumo terapija, grupinè terapija, autogeninès treniruotès. Palaipsniui nutrauktas prednizolonas nuo $20 \mathrm{mg}$ per keturias savaites pagal endokrinologu rekomendacijas. Stacionaraus gydymo metu skausminiai bei judejimo funkcijos sutrikimo skundai išliko, tik keitèsi jų lokalizacija. Nuolat skundèsi jègų neturèjimu, mieguistumu, dèl skausmo vengimo vaikščiojo letai, atsargiai. Nors pacientès vertinimu jos būklè nuo hospitalizacijos pradžios beveik nepakito, objektyviai stebètas veido formos pokytis (Kušingo sindromo redukcija). Paciente akcentavo, kad svarbiausi negalavimai - eisenos sutrikimai, kūno skausmai - neišnyko. Taip pat paciente abejojo prednizolono nutraukimo tikslingumu ir psichiatrinio gydymo sėkme. Skyriuje kartojosi priepuoliai, kurių metu buvo sustingusi, kalbejo skiemenuodama, nejudèjo, vèliau pati savaime atsigavo. Praejus ménesiui nuo atvykimo i psichiatrijos stacionarą prasidèjo karščiavimo epizodai iki $39^{\circ} \mathrm{C}$. Itarta pneumonija, kuri krūtinès ląstos rentgenogramos atmesta. Kraujyje nustačius leukocitozę, skirtas amoksiklavas $1500 \mathrm{mg} / \mathrm{d}$. Per kelias dienas karščiavimas praejjo. Po dviejų savaičių vèl prasidejo febrilus karščiavimas. Skyrus ciprofloksaciną 1000 $\mathrm{mg} / \mathrm{d}$., temperatūra sumažèjo, tačiau ịvertinus pacientès būklę, nesibaigiant kartotiniams neaiškios kilmès karščiavimams ir esant staigiems leukogramos pokyčiams nuspręsta pasiųsti pacientę į terapijos ligoninę. Rekomenduota toliau tęsti amitriptiliną ir lankytis pas psichiatrą ambulatoriškai.

Praejjus pusei metų nuo gydymo psichiatrijos stacionare pabaigos pacientė pakartotinai konsultuojasi su gydytojais, kartojami tyrimai. Imunologiniuose tyrimuose ANA, ANCA, anti ds-DNR neigiami, C3/C4, CK normos ribose, proteinograma, bendras kraujo tyrimas - be kliniškai reikšmingų pakitimų. Plaštakų, peties ir kelių sąnariai rentgenografijose ir peties bei kelio sąnario ultragarsiniai tyrimai be žymesnių pakitimų. Duomenų dèl pirminès reumatologinès patologijos nèra, gydymas neskiriamas, tačiau paciente toliau tęsia prednizolono vartojimą savo nuožiūra. Dar po kelių mėnesių endokrinologai nustatè lètinį antinksčiu nepakankamumą ir skyrè pakaitini gydymą gliukokortikoidais.

\section{Diskusija}

Šis retas klinikinis atvejis iliustruoja sudètingą ir kelerius metus užsitęsusią SFS eigą. Varginantys virškinimo funkcijos sutrikimai pacientę lydèjo nuo vaikystès, paauglystèje tirta gastroenterologų, neradus somatinès patologijos, itarta somatoforminè autonominė disfunkcija, tačiau gydymo atsisakyta. Paauglystejje atsiradusios plaštakų ir kelių senestopatijos ir senestalgijos laikui bėgant progresavo iki eisenos sutrikimų. Šalia skausminių skundų ryškejjanti adinamija ir anergija lèmè akademinę ir socialinę dezadaptaciją, pacientė nutraukè studijas, socialinius kontaktus. Greta skausmų i kitas kūno vietas bei autonominès nervų sistemos simptomų pasireiškimo prisidejjo hipochondrinès pervertinimo idejos, kurios kiekvienais metais intensyvejo dažnai lankantis pas įvairių sričių gydytojus nepaisant jų įtikinëjimų, jog simptomai neturi somatinio pagrindo. Kelis metus prieš patenkant ị psichiatrijos stacionarą intensyviai kartojamos gydytojų konsultacijos ir atliekami betiksliai tyrimai. Nerandant somatinès ligos intensyvejjančius simptomus paaiškinančios somatinès ligos, pakartotinai įtarta somatoforminè autonominè disfunkcija. Psichiatro rekomenduoto medikamento pacientė nevartojo dèl nepageidaujamų reakcijų. Tęsèsi gydytojų konsultacijos, tyrimai, ligos istorijoje atsirado funkciniai sutrikimai: reumatologai diagnozavo fibromialgiją, rekomendavo konsultuotis su gastroenterologais dèl dirgliosios žarnos sindromo. Greta somatinių simptomų kartojosi varginantys konversiniai judesių, kalbos sutrikimo priepuoliai su aiškia sąmone, be amnezijos, psichogeniniu provokuojančiu komponentu, kurie vieną dieną tapo svarbiu gydymo psichiatrijos stacionare motyvu. Besikartojančios įvairių specialistų konsultacijos ir tyrimai, gydytojų nesusitarimas ir kelių skirtingų diagnozių nustatymas sukelia pacientų nepasitikèjimą, neužtikrinamas efektyvus gydymas. Visa tai lèmé ne tik suprastejusią pacientès gyvenimo kokybę, bet ir sunkų piktnaudžiavimą medikamentais ir antrinių letinių ligų atsiradimą. Hospitalizacijos psichiatrijos ligoninèje metu paciente jau apie 1,5 
metus nepaisydama gydytojų rekomendacijų vartojo gliukokortikoidus, kurie sukèlè jatrogeninị Kušingo sindromą (KS). Trumpalaikiam vartojimui gydytojai šalutinei somatinei ligai gydyti skyrè prednizoloną, kuris sumažino pacientę varginančius simptomus ir ji savavališkai nusprende tęsti jo vartojimą. Literatūroje aprašomi atvejai, kada prednizolonas sukelia teigiamus afekto pakitimus net ir nepagerejus bendrai fizinei būklei. Šis poveikis pasireiškia laikinu depresijos, nerimo simptomų ir nuovargio sumažèjimu, o energijos didejjimas lydi gerą jauseną ar net euforiją (8). Tokie afekto pakitimai galèjo padidinti piktnaudžiavimo prednizolonu riziką. Taip pat sisteminis ir ilgalaikis gliukokortikoidu vartojimas lemia pagumburio-hipofizès-antinksčių (PHA) ašies slopinimą, dèl to mažejo AKTH gamyba pacientès organizme, tai lèmè antinksčių supresiją ir sumažino antinksčiu išskiriamo kortizolio kiekị (9). Ilgalaikis gliukokortikoidų vartojimas taip pat turèjo ịtakos antrinès arterinès hipertenzijos atsiradimui (10), aukštas pacientès kraujospūdis laikèsi net ir antihipertenzinių vaistų vartojimo pradžioje. Imuniteto slopinimas yra dar viena nepageidaujama reakcija sukelta piktnaudžiaujant prednizolonu ir gali lemti gyvybei pavojingų infekcijų atsiradimą (11). Stacionare nutraukiamas gliukokortikoidų vartojimas, tačiau pacientė išliko nekritiška ir nebuvo motyvuota nutraukti prednizolono vartojimo. Praejjus metams po hospitalizacijos psichiatrijos ligoninëje, pacientei išsivysto lètinis antinksčių nepakankamumas. Nors vis dar nežinoma, kuriems pacientams greičiau išsivysto antinksčių nepakankamumas vartojant gliukokortikoidus, rekomenduojama po dviejų ménesių gydymo steroidais atlikti laboratorinius AKTH ir kortizolio tyrimus, kad būtu galima ịvertinti antinksčių veiklą. Taip pat pacientai turètų būti informuojami apie KS ir antinksčių nepakankamumo išsivystymo galimybę, o atsiradus būdingiems požymiams kreiptųsi pas gydytoją (10).

Nustatant diagnozę tarptautinių ligų klasifikacijoje (TLK10-AM) pateikiami SFS skirstomi ị somatizacinị sutrikimą, nediferencijuotą somatoforminị sutrikimą, somatoforminę autonominę disfunkciją, nuolatinį somatoforminị skausmo sutrikimą, nespecifinị somatoforminị sutrikimą ir kitus somatoforminius sutrikimus (12). Jei dominuoja nerimas ir susirūpinimas, kad jau sergama viena ar keliomis somatinèmis ligomis, diagnozuojamas hipochondrinis sutrikimas. SFS diagnostiniai kriterijai yra painūs, apima abstrakčius negalavimus ir nepalankūs klinikinejje praktikoje $(13,14)$. Vyraujant vienos organų sistemos sutrikimui SFS diagnostiniai kriterijai persidengia su funkciniais sutrikimais. Šiu sindromų kriterijai specifiškesni ir orientuoti ị vieną ryškų simptomą, kaip antai Romos kriterijai dirgliosios žarnos sindromui, Oksfordo kriterijai lètiniam nuovargiui ar fibromialgijos kriterijai (15 -17). Atlikti tyrimai aiškiai įrodo, kad ịvairūs funkciniai sutrikimai nèra atskiros ligos ir turi bendrus patofiziologinius, diagnostikos ir atsako ị gydymą panašumus (18). Ivairių sričių gydytojai nevengia diagnozuoti kelių sindromų vienam pacientui, todèl tai tik dar labiau apsunkina diagnostikos procesą.

Nuo 2013 metų Diagnostiniame ir statistiniame psichinių ligų vadove (ang. Diagnostic and Statistical Manual of Mental Disorders) DSM-V somatizacini, nediferencijuotą somatoforminị ir skausmo sutrikimus keičia vienas vienintelis somatinio simptomo sutrikimas (ang. Somatic symptom disorder). Iš šios grupès atskiriamas hipochondrinis sutrikimas, kuris pavadintas ligos nerimu (ang. Illness anxiety disorder). Somatinio simptomo sutrikimas nebeturi vieno iš pagrindinių SFS kriterijaus, jog simptomas būtinai turi būti nepaaiškinamas mediciniškai ir išryškina naują pagrindinị kognityvinį kriterijų. Sunkūs ir ilgai besitęsiantys somatiniai negalavimai sukelia neadekvačias ir nuolatines mintis susijusias su paciento būkle, tai lemia nerimą ir dèl to keičiasi paciento elgesys, kada pernelyg daug laiko ir energijos skiriama rūpinimuisi dẻl sveikatos būklès. Diagnostikoje atkreipiamas dèmesys ị su ligą susijusią paciento emocinę būseną, mąstymą. Sekdama šiuo pavyzdžiu, Pasaulinè sveikatos organizacija vis dar plètoja būsimą TLK-11, tačiau jau užsimenama apie 3 naujų sutrikimų atsiradimą psichinių ligų kategorijoje. Vienas iš jų kūno distresinis sutrikimas, kuris turetų pakeisti funkcinius sutrikimus ir SFS, išskiriant hipochondrinị sutrikimą taip pat kaip atskirą. Naujają diagnostinę kategoriją tiksliausiai apibūdina jau seniai pasiūlytas ir tyrinèjamas kūno distresinis sindromas $(18,19)$. Naujoji diagnostinę kategoriją jungia tiek vienos konkrečios organy sistemos sutrikimus, tiek skirtingose kūno vietose pasireiškiančius simptomus. Kitaip nei DSM-V kūno distresiniu sutrikimu siekiama pabrèžti somatinius simptomus, kurie išsekina pacientą, sutrikdo kasdienį funkcionavimą, o ne sukelia kokị elgesị ar mintis (20).

\section{Išvados}

Šis retas klinikinis atvejis rodo sudetingą problemą klinikineje praktikoje susidūrus su simptomais, kuriuos norima pagrịsti atliekant daugybę tyrimų, tačiau galiausiai nerandama jokios somatinès patologijos. SFS diagnostiniai kriterijai tiksliausiai apibūdina šị simptomų pasireiškimą, tačiau jie painūs ir sunkiai pritaikomi klinikinèje praktikoje, o jų diagnostinių kriterijų persidengimas su funkciniais sutrikimais tik dar labiau apsunkina šių pacientų diagnostiką. Vienos konkrečios apibūdinančios diagnozès nebuvimas neužtikrina efektyvaus gydymo pasirinkimo. Tai sukelia ne tik paciento gyvenimo kokybès suprastejjimą, bet ir gali lemti piktnaudžiavimą medikamentais bei antrinių lètinių ligų išsivystymą. Ateityje tikimasi apjungti SFS ir funkcinius 
sutrikimus ị vieną naują diagnostinę kategoriją. Tai padètų lengviau atpažinti somatinius simptomus ir užtikrinti pacientams efektyvų ligos eigos valdymą ir gydymą.

\section{Literatūra}

1. Haller H, Cramer H, Lauche R, Dobos G. Somatoform disorders and medically unexplained symptoms in primary care. Dtsch Aerzteblatt Online 2015 Apr 17; Available from: https://www. aerzteblatt.de/10.3238/arztebl.2015.0279

https://doi.org/10.3238/arztebl.2015.0279

2. Henningsen P. Management of somatic symptom disorder. Dialogues Clin Neurosci 2018;20(1):9.

3. Möller H-J, Laux G, Deister A. Psychiatrie, psychosomatic and psychotherapie. Stuttgart: Georg Thieme Verlag KG; 2013. https://doi.org/10.1055/b-002-6253

4. Creed F, Guthrie E, Fink P, Henningsen P, RiefW, Sharpe M. et al. Is there a better term than "Medically unexplained symptoms"? J Psychosom Res 2010 Jan;68(1):5-8. https://doi.org/10.1016/j.jpsychores.2009.09.004

5. Schaefert R, Laux G, Kaufmann C, Schellberg D, Bölter R, Szecsenyi J. et al. Diagnosing somatisation disorder (P75) in routine general practice using the International Classification of Primary Care. J Psychosom Res 2010 Sep;69(3):267-77. https://doi.org/10.1016/j.jpsychores.2010.05.003

6. Henningsen P, Zipfel S, Herzog W. Management of functional somatic syndromes. The Lancet. 2007 Mar;369(9565):946-55. https://doi.org/10.1016/S0140-6736(07)60159-7

7. Rask MT, Ørnbøl E, Rosendal M, Fink P. Long-term outcome of bodily distress syndrome in primary care: a follow-up study on health care costs, work disability, and self-rated health. Psychosom Med 2017 Apr;79(3):345-57.

https://doi.org/10.1097/PSY.0000000000000405

8. Swinburn C, Wakefield J, Newman S, Jones P. Evidence of prednisolone induced mood change ('steroid euphoria') in patients with chronic obstructive airways disease. Br J Clin Pharmacol 1988 Dec;26(6):709-13.

https://doi.org/10.1111/j.1365-2125.1988.tb05309.x

9. Manubolu S, Nwosu O. Exogenous Cushing's syndrome secondary to intermittent high dose oral prednisone for presumed asthma exacerbations in the setting of multiple emergency department visits. J Clin Transl Endocrinol Case Rep 2017 Dec;6:4-8.

https://doi.org/10.1016/j.jecr.2017.07.001

10. Pektas SD, Dogan G, Cinar N. Iatrogenic Cushing's syndrome with subsequent adrenal insufficiency in a patient with psoriasis vulgaris using topical steroids. Case Rep Endocrinol 2017;2017:1-3.

https://doi.org/10.1155/2017/8320254

11. Paul EM, Jose S, Achar Y, Raghunath BD. Prednisolone induced Cushing syndrome: a case report. Indian J Pharm Pract 2016 Jun 1;9(2):141-2. https://doi.org/10.5530/ijopp.9.2.15

12. TLK-10-AM / ACHI / ACS elektroninis vadovas. Available from: http://ebook.vlk.lt/e.vadovas/index.jsp?topic=/ lt.webmedia.vlk.drg.icd.ebook.content/html/icd/5skyrius.html

13. Dimsdale JE, Creed F, Escobar J, Sharpe M, Wulsin L, Barsky A. et al. Somatic symptom disorder: an important change in dsM. J Psychosom Res 2013 Sep;75(3):223-8.

https://doi.org/10.1016/j.jpsychores.2013.06.033

14. Gureje O. Classification of somatic syndromes in ICD-11: curr opin psychiatry $2015 \mathrm{Sep} ; 28(5): 345-9$.

https://doi.org/10.1097/YCO.0000000000000186

15. Wolfe F, Clauw DJ, Fitzcharles M-A, Goldenberg DL, Häuser W, Katz RL. et al. 2016 Revisions to the 2010/2011 fibromyalgia diagnostic criteria. Semin Arthritis Rheum. 2016 Dec;46(3):319-29.

https://doi.org/10.1016/j.semarthrit.2016.08.012

16. Moayyedi P, Mearin F, Azpiroz F, Andresen V, Barbara G, Corsetti M, et al. Irritable bowel syndrome diagnosis and management: A simplified algorithm for clinical practice. United Eur Gastroenterol J 2017 Oct;5(6):773-88.

https://doi.org/10.1177/2050640617731968

17. Yancey JR, Hospital FBC, Belvoir F. Chronic fatigue syndrome: diagnosis and treatment. Chronic Fatigue Syndr 2012;86(8):6.

18. Fink P, Schröder A. One single diagnosis, bodily distress syndrome, succeeded to capture 10 diagnostic categories of functional somatic syndromes and somatoform disorders. J Psychosom Res 2010 May;68(5):415-26.

https://doi.org/10.1016/j.jpsychores.2010.02.004

19. Fink P, Toft T, Hansen MS, Ørnbøl E, Olesen F. Symptoms and syndromes of bodily distress: an exploratory study of 978 internal medical, neurological, and primary care patients. Psychosom Med 2007 Jan;69(1):30-9.

https://doi.org/10.1097/PSY.0b013e31802e46eb

20. Budtz-Lilly A, Schröder A, Rask MT, Fink P, Vestergaard M, Rosendal M. Bodily distress syndrome: a new diagnosis for functional disorders in primary care? BMC Fam Pract. 2015 Dec;16(1). Available from: http://bmcfampract.biomedcentral. com/articles/10.1186/s12875-015-0393-8

https://doi.org/10.1186/s12875-015-0393-8

\section{MISUSE OF PREDNISOLONE INDUCED CUSHING'S SYNDROME: A CASE REPORT K.Budrytė, M.Karnickas}

Key words: iatrogenic Cushing's syndrome, prednisolone, somatoform disorder, function disorder, bodily distress disorder.

Summary

Somatic symptoms, which have not been sufficiently explained by organic causes after a thorough physical examination, are core characteristic of the somatoform disorders. Somatic symptoms are highly prevalent in primary care, but somatoform disorders are underdiagnosed and its diagnostic criteria are conceptually overlapping with functional disorders. The objective of this clini- 


\section{4}

cal case report is to highlight severe and enduring course of somatoform disorders. Multiple consultations with negative investigation results and incomplete diagnosis associated with distrust of treatment and unsuccessful management of somatoform disorder. As a consequence, this have caused functional disability and severe misuse of prednisolone, which induced Cushing's syndrome and occurrence of chronic diseases. A new suggested diagnostic category, which may replace diagnostic categories of functional disorders and of the somatoform disorders, is discussed. This may solve the diagnostic challenge and ensure effective management and treatment of somatoform disorders.

Correspondence to: kbudrytes@gmail.com

Gauta 2019-05-09 